\title{
DAMPAK PENERAPAN PEMBELAJARAN DARING TERHADAP KEMANDIRIAN BELAJAR (SELF-REGULATED LEARNING) MAHASISWA PADA MATA KULIAH GEOMETRI SELAMA PEMBELAJARAN JARAK JAUH DI MASA PANDEMI COVID-19
}

\author{
Dianne Amor Kusuma \\ Departemen Matematika FMIPA Unpad, Jl. Raya Bandung Sumedang KM.21, Bandung, Indonesia \\ email: amor@unpad.ac.id
}

\begin{abstract}
The background of this research is widespread in Covid-19 in Indonesia and takes many casualties. One of the government's efforts to reduce the spread of the virus is to create policies for students and students throughout Indonesia to study at home until June 19, 2020. To keep the material delivered and the learning process is not interrupted by the condition, distance learning (PJJ) is carried out through online learning. This research aims to find out the extent to which the application of online learning impacts the independence of student learning during the implementation of PJJ in Geometry courses. In this study, the survey method was used against 45 students of S-1 Mathematics Study Program FMIPA Unpad Bandung class of 2019. The results showed that the application of online learning had a positive impact on the independence of student learning in Geometry courses during PJJ. It is recommended that further research be reviewed on the impact of online learning on student mathematical resilience during PJJ.
\end{abstract}

Keywords: Covid-19, distance learning, geometry, online learning, self-reliance

\section{ABSTRAK}

Latar belakang penelitian ini adalah penyebaran Covid-19 di Indonesia yang semakin meluas dan memakan banyak korban. Salah satu upaya pemerintah untuk mengurangi penyebaran virus ini adalah membuat kebijakan bagi para pelajar dan mahasiswa di seluruh Indonesia untuk belajar di rumah hingga 19 Juni 2020. Agar materi tetap tersampaikan dan proses pembelajaran tidak terganggu dengan kondisi tersebut, maka dilakukan Pembelajaran Jarak Jauh (PJJ) melalui pembelajaran daring. Penelitian ini bertujuan untuk mengetahui sejauhmana penerapan pembelajaran daring berdampak terhadap kemandirian belajar mahasiswa selama melaksanakan PJJ pada mata kuliah Geometri. Dalam penelitian ini digunakan metode survey terhadap 45 orang mahasiswa S-1 Program Studi Matematika FMIPA Unpad Bandung angkatan 2019. Hasil penelitian menunjukkan bahwa penerapan pembelajaran daring memberikan dampak positif terhadap kemandirian belajar mahasiswa pada mata kuliah Geometri selama PJJ. Sebaiknya pada penelitian selanjutnya dikaji pula mengenai dampak penerapan pembelajaran daring terhadap resiliensi matematis mahasiswa selama PJJ.

Kata kunci: Covid-19, geometri, kemandirian belajar, pembelajaran daring, pembelajaran jarak jauh,

Dikirim: 23 Mei 2020; Diterima: 25 Agustus 2020; Dipublikasikan: 30 September 2020

Cara sitasi: Kusuma, D. A. (2020). Dampak penerapan pembelajaran daring terhadap kemandirian belajar (self-regulated learning) mahasiswa pada mata kuliah geometri selama pembelajaran jarak jauh di masa pandemi covid-19. Teorema: Teori dan Riset Matematika, 5(2), 169-175. 


\section{PENDAHULUAN}

Covid-19 merupakan virus baru yang mewabah pertama kali di Wuhan, Tiongkok pada bulan Desember 2019. Virus ini menular dan penyebarannya sangat cepat hingga ke seluruh penjuru dunia, serta memakan banyak korban jiwa, tidak terkecuali di Indonesia. Untuk memperlambat penyebaran virus ini, pemerintah menghimbau agar seluruh penduduk Indonesia melakukan social distancing (pembatasan sosial), sehingga hampir semua kegiatan ekonomi, sosial, budaya, dan pendidikan dikurangi bahkan dihentikan sementara sampai batas waktu yang belum ditentukan. Untuk pendidikan, pemerintah secara resmi telah menginformasikan bahwa segala bentuk kegiatan pendidikan, mulai dari level pendidikan dasar hingga pendidikan tinggi, dihentikan mulai tanggal 16 Maret 2020 sampai dengan pemberitahuan selanjutnya, dan kegiatan pembelajaran tetap dilakukan dengan cara pembelajaran jarak jauh (PJJ), yakni antara pengajar dan peserta didik berada pada lokasi yang berbeda melalui media daring (online).

Karena kondisi dirasa belum aman, setelah 14 hari masa social distancing, beberapa perguruan tinggi di Indonesia memperpanjang masa PJJ hingga tanggal 19 Juni 2020. Untuk itu perlu dipersiapkan beberapa hal agar PJJ dapat berjalan dengan baik dan peserta didik (dalam hal ini, mahasiswa) tetap dapat mencapai kompetensi yang diharapkan. Moore (Nsiah, 2013) menyatakan bahwa PJJ adalah pembelajaran yang dirancang untuk peserta didik yang berada di tempat yang berbeda dengan pengajar. Adapun prinsip-prinsip umum dalam merancang PJJ adalah sebagai berikut: (1) proses pembelajaran dan bahan ajar harus dirancang dengan baik, jelas, dan konsisten; (2) tujuan pembelajaran harus jelas; (3) materi dan cara penyampaian materi pembelajaran disajikan dalam unit-unit kecil; (4) partisipasi yang terencana; (5) bahan ajar harus luas dan relevan; (6) materi yang penting harus diulang secara periodik; (7) ide penting dalam materi pembelajaran maupun ide dari peserta didik harus terjalin secara terpadu; (8) tampilan materi harus menarik; (9) materi pembelajaran harus disajikan dalam beberapa media yang berbeda agar menarik; (10) contoh-contoh, tugas, dan masalah yang diberikan harus terbuka (open ended); (11) peserta didik harus menerima umpan balik secara teratur atas kemajuan hasil belajarnya; dan (12) evaluasi secara rutin terhadap efektivitas belajar, media, serta metode pembelajaran (Moore \& Kearsley, 2005). Selain itu, dalam melaksanakan PJJ terdapat beberapa hal yang harus diperhatikan, yaitu: (1) ketersediaan jaringan internet yang mumpuni; (2) ketersediaan perangkat lunak dan perangkat keras bagi dosen maupun mahasiswa; (3) kesiapan dosen dan mahasiswa dalam menggunakan perangkat lunak dan perangkat keras; dan (4) ketersediaan materi pembelajaran yang telah didigitalisasi. Jika salah satu dari tiga hal tersebut tidak terpenuhi, maka PJJ tidak dapat berjalan dengan baik.

Selama pemerintah masih berupaya keras untuk memutus rantai penyebaran Covid-19, para mahasiswa seluruh perguruan tinggi di Indonesia melaksanakan PJJ melalui pembelajaran daring, yakni pembelajaran dengan bantuan teknologi berbasis internet yang sering disebut juga pembelajaran elektronik (Simarmata et al., 2018). Simarmata (2006) pun mengemukakan bahwa dalam teknologi pembelajaran terdapat dua metode yang dapat diterapkan yaitu sinkronus dan asinkronus. Pembelajaran dengan metode sinkronus adalah dosen dan mahasiswa berada di lokasi geografis yang berbeda namun dapat bertatap muka dan berinteraksi pada waktu yang bersamaan dalam jaringan internet. Sedangkan metode asinkronus adalah dosen dan mahasiswa tidak bertatap muka dan berinteraksi dalam waktu yang bersamaan. Dalam penelitian ini, peneliti menggunakan kedua metode tersebut dalam melaksanakan PJJ pada mata kuliah geometri.

Pelaksanaan PJJ tentunya akan berdampak pada hasil belajar mahasiswa, dan ini tidak terlepas dari kemandirian belajar mahasiswa. Artinya, PJJ membutuhkan kemandirian belajar yang tinggi dari peserta didik (dalam hal ini, mahasiswa) untuk dapat memahami materi yang diajarkan, karena kemandirian belajar berpengaruh positif terhadap hasil belajar (Handayani \& Hidayat, 2018). Darr \& Fisher (Supianti, 2016) dalam penelitiannya menemukan bahwa kemandirian belajar berkorelasi positif terhadap pencapaian hasil belajar peserta didik. Sedangkan yang dimaksud dengan kemandirian belajar adalah kegiatan belajar yang bersifat mandiri dan tidak bergantung pada orang lain (Ahmadi, 2004). Pendapat tersebut didukung pula oleh Umar \& Sulo (2005), yang mengemukakan bahwa kemandirian belajar adalah aktivitas belajar yang didorong oleh kemauan sendiri, pilihan sendiri, dan disertai rasa tanggungjawab dari diri pembelajar. Schunk \& Zimmerman (1998), menyatakan bahwa kemandirian belajar merupakan proses 
belajar yang terjadi karena pengaruh dari pemikiran, perasaan, strategi, dan perilaku sendiri yang berorientasi pada pencapaian tujuan. Fase utama dalam siklus kemandirian belajar (Schunk \& Zimmerman, 1998) meliputi: merancang belajar, memantau kemajuan belajar selama menerapkan rancangan, mengevaluasi hasil belajar secara lengkap, dan melakukan refleksi. Adapun rincian kegiatan yang berlangsung pada setiap fase kemandirian belajar (Sumarmo, 2010) adalah sebagai berikut:

1) Fase merancang belajar: menganalisis tugas belajar, menetapkan tujuan belajar, dan merancang strategi belajar.

2) Fase memantau: mengajukan pertanyaan pada diri sendiri tentang "Apakah strategi yang dilaksanakan telah sesuai dengan rencana?", "Apakah saya kembali kepada kebiasaan lama?", Apakah saya tetap memusatkan diri?", dan "Apakah strategi telah berjalan dengan baik?".

3) Fase mengevaluasi: memeriksa proses pelaksanaan strategi, hasil belajar yang telah dicapai, serta memeriksa kesesuaian strategi dengan jenis tugas belajar yang dihadapi.

4) Fase merefleksi: melakukan refleksi pada setiap fase selama siklus berjalan.

Supianti (2016) mengemukakan bahwa karakteristik kemandirian belajar adalah sebagai berikut: (1) individu mendesain belajarnya sendiri sesuai dengan kebutuhan atau tujuan individu yang bersangkutan; (2) individu memilih strategi dan melaksanakan desain belajarnya; dan (3) individu memantau kemajuan belajarnya sendiri, mengevaluasi, hasil belajarnya, serta membandingkan dengan standar tertentu. Kemandirian belajar memiliki beberapa indikator (Sumarmo, 2010), yakni: (1) memiliki inisiatif dan motivasi belajar intrinsik; (2) memiliki kebiasaan mendiagnosa kebutuhan belajar; (3) mampu menetapkan tujuan/ target belajar; (4) mampu memonitor, mengatur, dan mengontrol belajar; (5) memandang kesulitan sebagai tantangan; (6) mampu memanfaatkan dan mencari sumber yang relevan; (7) mampu memilih dan menerapkan strategi belajar; dan (8) mampu mengevaluasi proses dan hasil belajar. Berdasarkan uraian tersebut, kemandirian belajar mahasiswa sangatlah diperlukan karena kemandirian belajar merupakan salah satu komponen penting dalam mencapai hasil belajar yang baik, selain daripada itu kemandirian belajar pun sangat diperlukan terutama dalam kondisi saat ini dimana semua peserta didik diharuskan untuk belajar di rumah sampai pandemi Covid-19 berakhir dan Indonesia sudah dinyatakan aman.

Berdasarkan hasil studi pendahuluan yang dilakukan pada bulan Maret 2019 terhadap mahasiswa S-1 Program Studi Matematika FMIPA Unpad angkatan 2018, memperlihatkan bahwa kemandirian belajar mahasiswa masih rendah. Hal itu ditunjukkan dengan masih terdapat beberapa indikator kemandirian belajar yang belum dimiliki sebagian mahasiswa. Berdasarkan pengamatan yang dilakukan peneliti, terlihat bahwa sebagian mahasiswa masih bergantung pada instruksi dosen dalam belajar, dalam menentukan materi apa saja yang perlu dipelajari, masih terfokus pada perolehan nilai dan bukan pada kemampuan yang harus mereka kuasai dan kembangkan, serta mudah menyerah ketika dihadapkan pada permasalahan yang sulit. Kondisi tersebut tidak dapat dibiarkan karena akan berpengaruh pada hasil belajar mahasiswa.

Dalam kondisi saat ini di Indonesia, di masa pandemi Covid-19 yang memberlakukan PJJ bagi peserta didik mulai dari pendidikan dasar hingga perguruan tinggi, kemandirian belajar peserta didik (dalam hal ini, mahasiswa) sangatlah diperlukan. Mahasiswa tidak hanya dituntut untuk dapat memahami materi yang diajarkan secara mandiri, namun juga harus dapat menentukan materi apa saja yang mereka perlukan, mencari sumber yang relevan dengan kebutuhan mereka, memilih strategi pembelajaran, serta harus mampu mengevaluasi proses dan hasil belajar mereka. Agar kondisi di masa pandemi Covid-19 ini tidak berdampak negatif terhadap hasil belajar mahasiswa, maka perlu dilakukan upaya untuk meningkatkan kemandirian belajar mahasiswa, salah satunya adalah dengan penerapan pembelajaran daring. Penggunaan teknologi dalam pembelajaran dapat memberikan kesempatan kepada siswa untuk berkolaborasi dan saling komunikasi, sehingga dapat meningkatkan kemandirian belajar (Zakiah \& Fajriadi, 2020).

Pembelajaran daring memiliki beberapa kelebihan (Kuntarto, 2017), diantaranya: (1) mahasiswa dapat belajar di mana pun, kapan pun, dan dalam situasi apapun; (2) perkuliahan dapat dilakukan tidak hanya melalui proses tatap muka antar dosen dan mahasiswa; dan (3) mahasiswa tetap dapat belajar 
walau berada pada lokasi yang berjauhan dengan dosen. Berdasarkan kondisi di Indonesia saat ini, yang memberlakukan PJJ selama masa pandemi Covid-19, maka penelitian tentang dampak penerapan pembelajaran daring terhadap kemandirian belajar mahasiswa sangatlah perlu untuk dilakukan. Dalam penelitian ini, pembelajaran daring yang digunakan adalah Edmodo.

Edmodo merupakan situs jejaring pendidikan gratis yang menyediakan platform daring yang aman bagi dosen dan mahasiswa (Alshawi \& Alhomoud, 2016). Peneliti memilih Edmodo untuk diterapkan dalam pembelajaran daring karena platform ini memiliki banyak kelebihan yang memungkinkan dosen dan mahasiswa berinteraksi melalui fitur-fitur berikut: (1) penugasan; (2) pengajuan pertanyaan; (3) pengiriman tugas; (4) diskusi; (5) kuis; (6) pesan; (7) obrolan; (8) buku nilai; dan (9) umpan balik yang diberikan oleh dosen. Edmodo memungkinkan dosen untuk menyediakan materi yang berupa power point slides bersuara, file, gambar, dan foto, serta buku elektronik yang dapat diakses oleh mahasiswa. Edmodopun memudahkan dosen untuk melakukan penilaian (grading) tugas dan kuis secara otomatis. Selain daripada itu, Edmodo memungkinkan dosen untuk membuat tugas ataupun kuis terjadwal. Dalam tugas atau kuis terjadwal, dosen dapat mengatur batas waktu pengumpulan, sehingga dapat mengetahui serta mengontrol mahasiswa yang mengumpulkan tepat waktu ataupun tidak tepat waktu.

\section{METODE PENELITIAN}

Penelitian ini menggunakan metode survei terhadap 45 orang mahasiswa S-1 Program Studi Matematika FMIPA Unpad angkatan 2019 (semester II) pada mata kuliah geometri. Mahasiswa semester II dipilih sebagai target sampel berdasarkan pertimbangan berikut: (1) mata kuliah geometri diberikan pada semester II; dan (2) mulai tanggal 16 Maret 2020 perkuliahan geometri dilakukan secara daring dikarenakan pandemi Covid-19. Penelitian ini adalah penelitian deskriptif. Instrumen yang digunakan dalam penelitian ini meliputi: (1) skala kemandirian belajar; (2) lembar observasi terhadap kegiatan perkuliahan; dan (3) lembar wawancara. Skala kemandirian belajar yang digunakan adalah skala Likert yang memuat tiga puluh pernyataan yang terdiri atas sepuluh pernyataan tentang motivasi belajar (yang mewakili indikator nomor 1, 3, dan 5), sepuluh pernyataan tentang kemandirian belajar (yang mewakili indikator nomor 4, 7, dan 8), dan sepuluh pernyataan tentang fasilitas belajar (yang mewakili indikator nomor 2 dan 6). Berdasarkan hasil pengujian validitas item menunjukkan bahwa ketiga puluh pernyataan termasuk kriteria valid. 13 pernyataan diinterpretasikan sangat signifikan dan 17 pernyataan diinterpretasikan signifikan, serta nilai reliabilitas diperoleh sebesar 0,81 dan diinterpretasikan tinggi.

\section{HASIL DAN PEMBAHASAN}

\section{Hasil Analisis Skala Kemandirian Belajar}

Dalam penelitian ini, selama PJJ di masa pandemi Covid-19 yang dimulai tanggal 16 Maret 2020, proses pembelajaran dilaksanakan dengan menerapkan pembelajaran daring menggunakan Edmodo, melalui situs https://new.edmodo.com. Dosen pengampu mata kuliah Geometri dan setiap mahasiswa yang mengikuti perkuliahan ini harus memiliki akun Edmodo. Dengan memiliki akun Edmodo, mahasiswa dapat: (1) membaca buku elektronik yang diunggah oleh dosen pengampu; (2) membaca dan mengunduh bahan-bahan perkuliahan yang diunggah oleh dosen pengampu, yang berbentuk powerpoint bersuara ataupun tidak bersuara; (3) mengajukan pertanyaan ataupun mengemukakan pendapat kepada dosen pengampu melalui beranda, fitur komentar (comment), percakapan (chat), dan pesan (message); (4) mengerjakan tugas, kuis, dan ujian (UTS dan UAS) yang diberikan oleh dosen pengampu; serta e) melihat hasil pekerjaan mereka (tugas, kuis, dan ujian) berupa skor yang mereka capai, berikut umpan balik yang diberikan oleh dosen pengampu.

Pengisian skala kemandirian belajar dilakukan oleh 45 orang mahasiswa pada pertemuan ke-14 dengan tujuan untuk mengetahui dampak penerapan pembelajaran daring menggunakan Edmodo selama PJJ di masa pandemi Covid-19. Karena data skala kemandirian belajar yang diperoleh berbentuk skala data ordinal, maka data tersebut ditransformasi ke dalam skala data interval meggunakan Method of Successive Interval (MSI). Statistika deskriptif kemandirian belajar mahasiswa tersaji pada Tabel 1. 
Tabel 1. Statistika deskriptif kemandirian belajar

\begin{tabular}{lccccc}
\hline & N & Mean & Minimum & Maximum & Std. Deviation \\
\hline Kemandirian belajar & 45 & 89.86 & 63.10 & 115.08 & 10.83020 \\
Valid N (listwise) & 45 & & & & \\
\hline
\end{tabular}

Tabel 1 memperlihatkan bahwa mean kemandirian belajar yang dicapai mahasiswa pada mata kuliah Geometri adalah 89.86, termasuk dalam kriteria sangat baik (Purwanto, 2010). Itu artinya, penerapan pembelajaran daring menggunakan Edmodo membuat mahasiswa dapat melaksanakan seluruh fase kemandirian belajar dengan sangat baik.

Paris \& Winograd (Sumarmo, 2010) mengemukakan bahwa kemandirian belajar tidak hanya difokuskan pada kesadaran berpikir, penggunaan strategi, dan motivasi yang berkelanjutan, namun juga membantu peserta didik untuk menggunakannya dalam menyelesaikan masalah secara efektif. Selain itu, peserta didik pun dapat membedakan masalah yang produktif dan tidak produktif, untuk dapat mempertimbangkan berbagai pilihan sebelum menentukan solusi. PJJ dengan menerapkan pembelajaran daring dapat pula meningkatkan kemampuan serta kinerja peserta didik, dan hal ini disebabkan penggunaan internet dapat mengirimkan deretan solusi yang luas (Rosenberg, 2001). Penggunaan Edmodo dalam pembelajaran matematika memiliki banyak manfaat, yakni pembelajaran menjadi lebih menarik dan menyenangkan, komunikasi antara mahasiswa dan dosen menjadi lebih mudah, pembelajaran dapat dilakukan tanpa dibatasi waktu dan tempat, serta dapat meningkatkan pemahaman mahasiswa (Sudarsi, 2017). Berdasarkan uraian tersebut, dapat dikatakan bahwa penerapan pembelajaran daring dengan menggunakan Edmodo berdampak positif terhadap kemandirian belajar mahasiswa dalam mata kuliah Geometri selama PJJ di masa pandemi Covid-19.

\section{Hasil Analisis Data Aktivitas Mahasiswa Selama Pembelajaran}

Aktivitas mahasiswa selama 10 minggu PJJ dengan menerapkan pembelajaran daring menggunakan Edmodo, diamati setiap 10 menit dan menandai aktivitas yang dominan dilakukan oleh mahasiswa. Aktivitas yang diamati meliputi: (1) keaktivan memberikan komentar terhadap bahan pembelajaran yang diunggah oleh dosen; (2) keaktivan mengajukan pertanyaan; (3) keaktivan mengemukakan pendapat; (4) keaktivan memberikan tanggapan terhadap komentar/pendapat mahasiswa lain; (5) keaktivan mencari informasi dari sumber lain berkenaan dengan pokok bahasan yang diajarkan; (6) keaktivan berdiskusi dengan mahasiswa lain; (7) kegesitan dalam menemukan solusi dari masalah yang diberikan dosen; (8) kegesitan dalam mengerjakan tugas/kuis yang diberikan dosen; (9) kreativitas dalam memberikan solusi; dan (10) ketepatan waktu dalam mengumpulkan tugas/kuis.

Berdasarkan pengamatan yang dilakukan selama 10 minggu, diperoleh rerata persentase aktivitas mahasiswa sebesar $80.16 \%$ dan termasuk kriteria aktif. Dari sepuluh aktivitas yang diamati, terdapat tiga aktivitas yang mendominasi, yaitu keaktivan mengajukan pertanyaan, keaktivan mencari informasi dari sumber lain berkenaan dengan pokok bahasan yang diajarkan, serta kegesitan dalam mengerjakan tugas/kuis yang diberikan dosen. Dengan demikian, dapat dikatakan bahwa penerapan pembelajaran daring menggunakan Edmodo membuat mahasiswa lebih aktif dalam proses pembelajaran.

Arifin \& Herman (2018), mengemukakan bahwa penerapan pembelajaran daring dapat: (1) membuat peserta didik memiliki lebih banyak kesempatan dalam memanfaatkan pengetahuan dan keterampilan matematika yang telah mereka miliki; (2) membuat peserta didik berpartisipasi aktif dalam pembelajaran serta aktif dalam mengekspresikan ide-ide mereka; (3) menstimulus peserta didik untuk merespon permasalahan dengan cara mereka sendiri; (4) membuat peserta didik lebih termotivasi untuk memberikan bukti dan penjelasan berdasarkan strategi yang mereka pilih untuk memecahkan permasalahan; dan (5) membuat pengalaman peserta didik menjadi lebih luas sehingga pemahaman konsepnya lebih meningkat. Dalam penelitiannya, Arifin \& Herman (2018) menemukan bahwa penerapan pembelajaran daring mendorong peserta didik belajar lebih aktif. Dari uraian tersebut, maka dapat dikatakan bahwa penerapan pembelajaran daring menggunakan 
Edmodo membuat mahasiswa terlibat lebih aktif dalam proses pembelajaran pada mata kuliah Geometri selama PJJ di masa pandemi Covid-19.

\section{Hasil Analisis Data Wawancara}

Wawancara tertulis dilakukan pada 45 orang mahasiswa pada pertemuan ke-14, dengan tujuan untuk mengumpulkan informasi mengenai respon mahasiswa terhadap penerapan pembelajaran daring menggunakan Edmodo selama PJJ di masa pandemi Covid-19. Dari wawancara yang dilakukan, diperoleh informasi sebagai berikut: (1) mahasiswa merasa tertarik belajar Geometri melalui pembelajaran daring menggunakan Edmodo; (2) mahasiswa merasa bahwa belajar Geometri melalui pembelajaran daring menggunakan Edmodo lebih menyenangkan daripada pembelajaran tatap muka; (3) mahasiswa merasa bahwa belajar Geometri melalui pembelajaran daring menggunakan Edmodo membuat mereka tidak merasa malu untuk bertanya kepada dosen karena mereka dapat bertanya melalui beberapa fitur yang disediakan (chat dan message); (4) mahasiswa merasa lebih termotivasi untuk mengerjakan tugas/kuis yang diberikan dosen; (5) mahasiswa dapat lebih lebih leluasa untuk mencari bahan pembelajaran melalui sumbersumber lain, untuk memperkaya pemahaman mereka; (6) mahasiswa dapat berkomunikasi dan bertanya kepada dosen berkenaan dengan mata kuliah Geometri, kapan pun dan di mana pun; dan (7) mahasiswa lebih bersemangat untuk mengumpulkan tugas tepat waktu.

Covington (Saphiro, 1997) mengemukakan bahwa ketertarikan dan motivasi peserta didik terhadap pembelajaran merupakan penentu utama keberhasilan mereka dalam suatu mata pelajaran atau mata kuliah yang mereka pelajari. Itu artinya, jika peserta didik tidak memiliki ketertarikan serta motivasi yang tinggi untuk mengikuti kegiatan pembelajaran maka akan berdampak pada hasil belajar mereka. Berdasarkan uraian tersebut, maka penggunaan Edmodo dalam pembelajaran daring untuk mata kuliah Geometri selama PJJ di masa pandemi Covid-19 dapat membuat mahasiswa lebih tertarik dan termotivasi untuk belajar.

\section{KESIMPULAN}

Hingga saat ini belum dapat dipastikan kapan pandemi Covid-19 akan berakhir, serta pemerintah Indonesia pun belum memutuskan secara resmi kapan para peserta didik (mulai dari tingkat dasar hingga perguruan tinggi) dapat kembali belajar secara normal. Oleh sebab itu perlu diupayakan cara agar proses pembelajaran tetap berlanjut dan para peserta didik (dalam hal ini, mahasiswa) tetap dapat melaksanakan kegiatan pembelajaran, sehingga kondisi di Indonesia saat ini tidak berdampak negatif terhadap hasil belajar mahasiswa. Salah satunya adalah PJJ dengan penerapan pembelajaran daring menggunakan Edmodo. Dalam PJJ dengan penerapan pembelajaran daring menggunakan Edmodo, hasil belajar mahasiswa pun tidak terlepas dari kemandirian belajar mereka, karena untuk dapat memahami materi yang diajarkan, kemandirian belajar sangatlah diperlukan. Hasil penelitian menunjukkan bahwa penerapan pembelajaran daring menggunakan Edmodo selama PJJ di masa pandemi Covid-19 berdampak positif terhadap kemandirian belajar mahasiswa dalam mata kuliah Geometri. Penerapan pembelajaran daring menggunakan Edmodo pun membuat mahasiswa lebih aktif dalam proses pembelajaran, serta membuat mereka lebih tertarik dan termotivasi untuk belajar.

\section{REKOMENDASI}

Dari kesimpulan yang telah dikemukakan, peneliti mengajukan beberapa rekomendasi antara lain: (1) dalam pemberian tugas pada penerapan pembelajaran daring, sebaiknya lebih memicu kreativitas mahasiswa sehingga mereka tidak hanya terpaku dan merasa puas pada bahan pembelajaran yang diberikan dosen; (2) agar dalam penerapan pembelajaran daring menggunakan Edmodo, dosen lebih sering memberikan komentar dan umpan balik pada setiap tugas, kuis, serta ujian yang dikerjakan mahasiswa, karena itu dapat membuat mereka merasa dihargai dan lebih bersemangat untuk memberikan hasil yang lebih baik lagi; dan (3) agar pada penelitian selanjutnya 
dikaji juga mengenai dampak penerapan pembelajaran daring menggunakan Edmodo terhadap resiliensi matematis (mathematical resilience) mahasiswa dalam mata kuliah Geometri.

\section{UCAPAN TERIMA KASIH}

Peneliti mengucapkan terimakasih kepada Pusat Studi Etnosains FMIPA Unpad, juga kepada Kaprodi Matematika FMIPA Unpad yang telah memberikan dukungan dalam penelitian ini.

\section{DAFTAR PUSTAKA}

Ahmadi, A. (2004). Teknik belajar yang efektif. Jakarta: PT. Rineka Cipta.

Alshawi, S. T., \& Alhomoud, F. A. (2016). The impact of using edmodo on saudi university EFL students' motivation and teacher-student communication. International Journal of Education, 8(4), 105-121.

Arifin, F., \& Herman, T. (2018). Pengaruh pembelajaran e-learning model web centric course terhadap pemahaman konsep dan kemandirian belajar matematika siswa. Jurnal Pendidikan Matematika, 12(2), 1-12.

Handayani, N., \& Hidayat, F. (2018). Hubungan kemandirian terhadap hasil belajar siswa mata pelajaran matematika di kelas X SMK kota cimahi. Journal on Education, 1(2), 1-8.

Kuntarto, E. (2017). Keefektifan model pembelajaran daring dalam perkuliahan bahasa indonesia di perguruan tinggi. Journal Indonesian Language and Literature, 3(1), 99-110.

Moore, M. G., \& Kearsley, G. (2005). Distance education: a system view. Belmont, CA: Thomson Wadsworth.

Nsiah, G. K. B. (2013). Best practices education: a review. Creative Education Journal, 4(12), 96-110.

Purwanto, N. (2010). Prinsip-prinsip dan teknik evaluasi pengajaran. Bandung: PT. Remaja Rosdakarya.

Rosenberg, M. J. (2001). Building successful online learning in your organization e-learning strategies for delivering knowledge in the digital age. New York: McGraw Hill.

Saphiro, L. (1997). Mengajarkan emotional intelligence pada anak. Jakarta: Gramedia.

Schunk, D. H., \& B. J. Zimmerman. (1998). Introduction to the self regulated learning (SRL) cycle. New York: The Guilford Press.

Simarmata, J. (2006). Pengenalan teknologi komputer dan informasi. Yogyakarta: Andi.

Simarmata, J., Djohar, A., Purba, J., \& Juanda, E. A. (2018). Design of a blended learning environtment based on merrill's principles. J. Phys.: Conf. Ser. 954(1), 1-6.

Sudarsi. (2017). Pengaruh efektivitas penggunaan edmodo terhadap kepuasan siswa di SMKN 1 surabaya. Jurnal Ekonomi Pendidikan dan Kewirausahaan, 5(2), 246-262.

Sumarmo, U. (2010). Kemandirian belajar: apa, mengapa, dan bagaimana dikembangkan pada peserta didik. http://math.sps.upi.edu/wp-content/uploads/2010/02/KEMANDIRIANBELAJAR-MAT-Des-06-new.pdf. Diakses 8 Mei 2020.

Supianti, I. (2016). Dampak penerapan e-learning dalam pembelajaran matematika terhadap kemandirian belajar mahasiswa. Teorema: Teori dan Riset Matematika, 1(1), 1-6.

Umar., \& La Sulo. (2005). Pengantar pendidikan. Jakarta: PT. Rineka Cipta.

Zakiah, N. E., \& Fajriadi, D. (2020). Hybrid-PjBL: Creative thinking skills and self-regulated learning of pre-service teachers. J. Phys.: Conf. Ser. 1521 032072. doi:10.1088/17426596/1521/3/032072. 